\title{
The Harvard Tercentenary Celebrations
}

$\mathrm{H}^{\mathrm{A}}$ ARVARD celebrated its tercentenary on September 18 by a ceremony which was as impressive in its setting as it was comprehensive in its conception.

The scene was set in the "Yard" ; for those to whom Harvard is a name, albeit a great name, a word must be said about the actual terrain. The Yard at Harvard, which forms the nucleus of the University, is situated in the town of Cambridge much as Trinity College is situated in Dublin; the buildings are less regularly disposed than those of the colleges at Cambridge or Oxford, and being detached from one another the arrangement into definite 'Courts' or quadrangles is less defined. The quadrangles, in so far as they exist, however, differ from those in the English universities in that they are planted with trees as well as with grass and therefore shaded completely with foliage. Of these leafy areas in the 'Yard', that which most definitely resembles a quadrangle is one bounded by the Memorial Church on the north and by the Widener Library on the south, both noble buildings, each at the head of an imposing flight of steps, and facing one another one hundred and thirty yards apart.

In this court the ceremony took place. The steps of the Memorial Church formed a terraced stage, from the centre of which the addresses were given. In the centre sat also the President of the United States, an old Harvard graduate, and the diplomatic and civic representatives, including Mr. Curley, Governor of Massachusetts. To the right and left sat the recipients of honorary degrees, and in the tiers behind them the delegates from other universities and corporations, and also the representatives of the faculties at Harvard. As the number of delegates was in the region of five hundred, there cannot have been less than one thousand persons who faced the assembly. For it fourteen thousand chairs had been placed in the court. "In the court" is perhaps not a good phrase, for at the back on each side of the Widener Library there is a gap in the buildings, and the rows of chairs stretched out into these two gaps until they were lost to sight beneath the trees.

The actual proceedings lasted about three hours. Over the whole of this colourful assembly hung the menace of storm. The weather for the precoding days had been perfect; but a hurricane was known to be on its way, travelling up the Atlantic coast. Rain-drops fell at the commence. ment of the proceedings and from time to time during its continuance, but the President, with resolution amply justified by the event, refused to transfer the programme to an alternative one which had been arranged in the event of wet weather. All knew that it was a race with time. Ten minutes before the termination of the sitting the skies broke, but the torrent of rain which poured from the clouds was no more than a reminder of what might have been. To some indeed the conditions may have seemed in a sense an allegory. What better symbol could there be of the determined growth of a University through three centuries of difficulty and strife to its present magnificence than the resolution of its President in carrying the tercentenary celebration to its climax through three hours of menacing storm.

The proceedings opened with a prayer and closed with a benediction $-a$ detailed account of them would perhaps be out of place. Items of particular interest to English readers would perhaps be : (1) The fact that shortly after the opening prayer the chimes of Southwark Cathedral, that in which John Harvard was baptized, were broadcast across the Atlantic and listened to by the audience. (2) The Poet Laureate of England, John Masefield, who travelled 3,000 miles to deliver his tribute in verse . . . which, referring to John Harvard, concluded :

"Would that his human eyes untimely dead,

Freed from that quiet where the generous are, Might see this scene of living corn made bread, This lamp of human hope become a star."

(3) The conferment of honorary degrees. The degree of doctor of science was conferred as follows :

Prof. E. B. Bailey-a British geologist whose skilful questioning of the Scottish highlands drew forth revealing answers, telling of the origin of mountain ranges and their evolution in the past.

Dr. Kiyoshi Shiga-the discoverer of the cause of epidemic dysentery, a valiant and effective fighter in the international struggle for the prevention of disease.

Prof. T. Levi-Civita-a mathematician great in accomplishment, an intellectual leader of the land we all revere, the birthplace of the art and science of the present day.

Sir Arthur Eddington-a student of the cosmos who peers within the atom and surveys the expanding universe, an expounder to the multitude of the poetry of modern science.

Prof. A. H. Compton-a physicist who forces light itself to illumine the dark secrets of its still mysterious nature. 
Prof. L. Ruzicka-a chemist, daring in his attack, brilliant in his methods, successful in his interpretations of the architecture of Nature's baffling compounds.

Prof. B. A. Houssay - a physiologist noted for his studies of the ductless glands, a leader of science in the new world to the south.

Sir Joseph Barcroft--an investigator of many phases of the respiration of higher animals, a beloved guide to younger men on both sides of the Atlantic.

Prof. C. Gini-a versatile sociologist and statistician who early turned his attention to that most vital problem, the growth of populations.

Prof. B. Malinowski-an anthropological explorer who initiated a new movement for the study of the gregarious habits of the human race.

Prof. J. Hjort-the naturalist of the northern sea, whose studies and explorations have benefited alike the science of biology and the fisheries of his native land.

Dr. F. Bergius-a modern magician, his knowing touch transforms coal to oil.

Dr. N. L. Bowen-a scientific Vulcan, in his laboratory furnaces he measures those forces which once formed our igneous rocks.

Prof. E. D. Adrian-a physiologist whose brilliant experimentation established new principles concerning nerve impulses and the action of sense organs.

Prof. P. M. F. Janet-a pioneer in studying the multifarious phenomena of mental pathology, his systematic analysis founded a branch of psychology

Prof. J. B. Collip-a skilful biochemist, a bold explorer among the tangled complexities of the internal secretions.

Prof. A. Pannekoek-an astronomer who has gauged the distances of the dark nobulae, an astrophysicist who has assayed the stellar atmospheres.

Prof. E. J. Cartan-a versatile investigator in the realm of pure thought, a mathematician who has advanced his science on many fronts.

Prof. P. Debye -a large-hearted physicist who gladly lends the chemist a helping hand by elucidating the electrical properties of matter.

Prof. The Svedberg - a man who sees beyond the microscope, at his bidding centrifugal forces make giant molecules reveal their size.

Prof. H. Spemann-a biologist who experimented with embryonic tissue and discovered a new approach to those agents which determine organic form.

Prof. C. G. Jung-a philosopher who has examined the unconscious mind, a mental physician whose wisdom and understanding have brought relief to many in distress.

Prof. L. E. Dickson-a fruitful speculator on the significance of numbers, an algebraist noted for his stimulating work.

Prof. R. G. Harrison-an embryologist whose method of transplantation yields new insight into the process of development.

Prof. R. A. Fisher--a student of heredity, who has improved statistical methods and assisted agriculture by the application of his science.

Prof. S. A. S. Krogh-a physiologist for ever probing with new instruments the unknown mechanism of life processes.

Dr. K. Landsteiner - the master of the science of immunology, the discoverer of those fundamental principles which made blood transfusion possible, saving countless lives.
Prof. G. H. Hardy-a British mathematician who has led the advance to heights deemed inaccessible by previous generations.

Prof. A. C. Lawson-a geologist who has ranged widely both in time and space.

Dr. J. H. Northrop-a chemist turned biologist, a skilled manipulator of those catalysts on which life depends.

Dr. F. Silvestri-a brilliant entomologist who has searched many continents to find those parasites which guard our crops.

Prof. H. Fischer - a master builder of molecular structure whose labours tell us why grass is green and blood is red.

Prof. R. Carnap-a philosopher of penetrating insight who lights the way for those who seek through logic the unity of the world.

Sir Frederick Gowland Hopkins-the discoverer of the vitamins, a pioneer in many fields, whose work stands as a symbol of the ceaseless adventure of the human mind.

Among the other awards, the honorary degree of doctor of letters was conferred on the following, among others :

Prof. J. Piaget - a deft inquirer into the growth of those mental processes which mark the gradual development of the normal child.

Prof. V. Gordon Childe-a far-seeing archæologist whose writings allow us to behold the dawn of civilization in Central Europe.

Prof. R. Maunier-a contributor to our under. standing of the functioning of social institutions, the director of research into the laws of simpler peoples in the colonies of France.

Prof. P. Pelliot-an intrepid explorer whose examination of the manuscripts and art of central Asia enhances our appreciation of a group of ancient cultures.

Dr. R. M. MacIver-an inquirer into the structure of society, a learned systematizer of our social theories.

Prof. M. I. Rostovtzeff-the social and economic historian of the Roman empire, whose fruitful study of antiquity accumulates for all who read centuries of rich experience.

(4) The most interesting feature of all was the oration of President Conant, a man, be it remembered, of less than forty-five years of age and until two years ago professor of chemistry, the courage and eloquence of which cannot be con. veyed in a few words. Starting with the President's conception of the proper ordering of a university, the oration developed into a plea for citizenship based upon the search for truth in all departments of intellectual activity. To the man of science it was interesting to observe that to President Conant the health of a university depends upon the maintenance of a correct balance between four components: student life, the teaching of abstract subjects, professional training, and the search for new knowledge. Typical of the later part of the speech was the demand for "absolute freedom of discussion, absolutely unmolested 
enquiry". This note of freedom was struck also by the President of the United States in his speech to the alumni of Harvard the same afternoon. "In this day of modern witch-burning, when freedom of thought has been exiled from many lands which were once its home, it is the part of Harvard and America to stand for the freedom of the human mind and to carry the torch of truth."

So much for the eighteenth of September, but it was only the climax. The proceedings of the two days previous may be passed over, though either of them would furnish matter for an interesting article. Rather would we go back to events still earlier and to a phase of the celebrations which possibly is without precedent.

Harvard determined if possible to make its celebration primarily an intellectual one. Before inviting universities and other corporations to send delegates, it drew out a list "of leading scholars in different parts of the world to a number which we trust will bring to the proposed conference some sixty or seventy men of high distinction from the whole field of learning". These received invitation to take part in a conference the intention of which was expressed in the following words: "It is hoped that we shall succeed in finding a meeting ground on which it will be possible not only for the results of research in detail to be communicated by scholars, to one another, but also for problems which concern a variety of disciplines to be the object of common attack."

The event proved overwhelmingly successful, so far, at least, as the present writer was able to judge from the proceedings kindred to his own subject, and from what he was told concerning others.

These 'proceedings', as indicated in the above quotation from the letter of invitation, fell into several forms. There were addresses on the general aspect of one broad subject such as that by $\mathrm{Sir}$ Frederick Hopkins on "The Influence of Chemical Thought on Biology" ; "Diabetes as a Disturbance of Endocrine Equilibrium", by Prof. Bernardo Alberto Houssay; "Insect Polyembryony and its General Biological Aspects", by Prof. Filippo Silvestri; "Plants and Civilisations", by Prof. Elmer Drew Merrill. There were sittings devoted to a group of kindred subjects such as that on the "Applications of Chemistry to Biology" in which the individual papers were: (1) "The Use of Isotopes as Indicators in Biological Research", by Prof. August Krogh ; (2) "The Formation of Enzymes", by Dr. John Howard Northrop; (3) "Protein Molecules", by Prof. The Svedberg.

There was no possibility of discussion on the great scale, but the effective 'meeting ground' was found in another way-after the communications, groups of those interested in the subject met and thrashed the matter out, or tried to do so. To take an example, after a communication on "The Fundamental Nature of the Respiratory Rhythm", a group consisting of two experimental psychologists, two pharmacologists, one physiologist and three anatomists had a most fruitful discussion on the initiation of neuro-muscular function in the fœtus, and one which will probably clear up many existing divergences of opinion. Such in its small measure admirably fulfilled the desire of Harvard "for problems which concern a variety of disciplines to be the object of common attack".

On this great scale, the same object was attained by the institution of symposia. These were classified as follows (Nos. 4 and 5 really were not symposia in the same ordered sense as 1, 2 and 3 ; they were groups of communications of the type of and including those already discussed) :

(1) Factors determining Human Behaviour.

(2) Authority and the Individual.

The State and Economic Enterprise; Stability and Social Change; The Place and Functions of Authority ; Classicism and Romanticism.

(3) Independence, Convergence and Borrowing in Institutions, Thought and Art.

Europe and the Near East; The Middle Ages; East and West.

(4) Biological Sciences.

Various Aspects of Biology; Experimental Morphology ; Parasitism; The Applications of Physical Chemistry to Biology.

(5) Physical Sciences.

Mathematics, Astrophysics, Cosmogony (Sessions of the American Mathematical Society and the American Astronomical Society); Theoretical Physics; Cosmic Radiation; Nuclear Physics; Geology and Geophysics; Chemistry ; Industrial Chemistry ; Communication Engineering.

The first of the above symposia was attended by the complete conference in joint session and was indeed the inaugural meeting. The remaining four represented the four divisions into which learning was divided for purposes of convenience-human relations, arts and letters, biological sciences, and physical sciences.

As an example of how the plan worked in detail, the first symposium may be taken. The intention was to sample various aspects of the activity of the human nervous system, from the most simple to the most complex. The opening paper was by Prof. E. D. Adrian on the objective physiology of "The Nervous System". This was followed by papers on "Hormones in Relation to Human Behaviour", by Prof. J. B. Collip, "Les principaux facteurs determinant l'evolution intellectuelle de l'enfance à lâge adulte et de la genese des 
principes de conservation", by Prof. Jean Piaget, "Psychological Factors determining Human Behaviour", by Prof. Charles Gustav Jung, "La force et la faiblesse psychologique", by Prof. Pierre Marie Félix Janet, "Logic", by Prof. Rudolf Carnap, "An Example from the Evidence of History", by President Emeritus Abbott Lawrence Lowell, and finally "Culture as a Determinant of Behaviour", by Prof. Bronislaw Malinowski.

The last of these took the form of an evening lecture. Other public lectures treating of subjects of general interest were by Frank Baldwin Jewett, of the Bell Telephone Laboratories in New York, on "The Social Implications of Scientific Research in Electrical Communication"; by Prof. Wm. Berryman Scott, on "The Laws of Mammalian Evolution"; by Sir Arthur Stanley Eddington, on the "Constitution of the Stars"; by Prof. G. H. Hardy, on "The Indian Mathematician, Ramanujan"; by Prof. E. J. Dent, on "The Historical Approach to Music" ; by Prof. Corrado Gini, on "Authority and the Individual during the Different Stages of Evolution of the Nations"; by Prof. John Dewey, on "Authority and Resistance to Social Change" ; by Prof. W. E. Rappard, on "Economic Nationalism"; and by Prof. Johan Hjort, on the "Biology of Whales".

Reviewing the activities of the congress, or such of them as fall within the scope of a biologist, it can only be said that the event far exceeded what might have been expected of it. It may be doubted whether any congress covering so wide a field has ever succeeded in at once reaching a level so sustained in matter, and in manner so intelligible to those not acquainted with the particular and specialized techniques of those who rose to so high a level.

Lastly, a word as to the hospitality poured with both hands upon the members of the congress. It is difficult to know where to begin or end in treating of it. American hospitality is the high water mark; to say that it reached the highest level of American hospitality is no less than the truth. One item, however, must be mentioned specifically, namely, the orchestral concerts, three in number, given by the Boston Symphony Orchestra. Two were instrumental, in the third the orchestra combined with the chorus of Harvard University and Radcliffe College. All were a sheer delight. At the close of the last concert, just before "Fair Harvard" was sung, President Conant walked up the hall, ascended the platform, shook hands with Dr. S. Koussevitzky, whose skill and enthusiasm as a conductor had been so largely responsible for this feast of pleasure. Dr. Conant said a few words, ending as follows: "I wish to say just two words 'Thank you'." A fitting ending, for there is no delegate who can have left Harvard with any other thought in his mind. Harvard--Thank you !

\section{The Patterns of Experience*}

\section{By A. W Wolters}

SUMMING up his important contributions to $S$ the psychology of perception, Prof. E. Rubin demonstrated, in a paper devoted to the 'ways of seeing' read before Section $J$ of the British Association at Norwich last year, that perceptual cognition is shot through with suggestions of movement and direction which are not reducible to the geometry of the object. The mind contributes structural principles to its own experience.

Like many scientific theories, this was not new. Many besides Rubin, and many earlier than he, have suggested that the mind, at least in part, makes its own experience. The value of his contribution lies in the beauty of his experimental development of the theme, and in the detailed application of it. But at least one of his demon-

* From the presidential address to Section $J$ (Psychology) of the British Association, delivered at Blackpool on September 11. strations at Norwich was so new as to be thrilling. Those who were present will remember vividly how we were brought to recognize that pictures in European art have a definite left-to-right. character, upon which their meaning and æsthetio appeal largely depend. I reported this to $\mathrm{Mr}$. Betts, the head of the School of Art in the Univer. sity of Reading. We went through his stock of lantern slides, and found that in nearly every case Rubin was clearly right. But our most exciting moment was that in which we discovered a drawing in which Rembrandt had gone astray. My colleague suggests that Rembrandt made his sketch from a mirror, a quite usual method, so that having posed his model correctly-that is, as Rubin would have had him do-and being absorbed by the technical problems of his sketch, he over looked the extraordinary and unpredictable effects of the lateral inversion. 